TITLE:

\title{
Visualization of the cervical spinal cord with FDG and high-resolution PET.(Abstract_要旨)
}

$\operatorname{AUTHOR}(S)$ :

Kamoto, Yoko

\section{CITATION:}

Kamoto, Yoko. Visualization of the cervical spinal cord with FDG and high-resolution PET.. 京都大学, 2001, 博士(医学)

ISSUE DATE:

2001-03-23

URL:

http://hdl.handle.net/2433/150547

RIGHT: 
氏 名 賀 本 陽 光

学位 (専攻分野) 博 士 (医 学)

学位記番号医 博 第 2351 号

学位授与の日付 平成 13 年 3 月 23 日

学位授与の要件 学 位 規 則 第 4 条第 1 項該 当

研究科. 専攻医学研究科内科系専攻

学位論文題目 Visualization of the cervical spinal cord with FDG and high-resolution PET.

(FDG と高分解能 PET による頝髀の可視化に関する研究)

論文調査委員教授柴 崎 浩 教授福山秀直 教 授小西淳二

\section{論 文 内 容 の 要 旨}

ポジトロン CT (PET) を用いた生体の糖代謝イメージング技術は脳, 心臓, 悪性腫瘍の研究や診断に広く用いられるに 至っている。しかし，脊髄の研究におけるPET 検査の役割はこれまで確立されていない。これは従来の PET 装置の空間

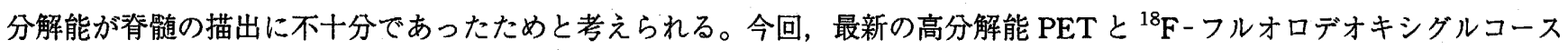

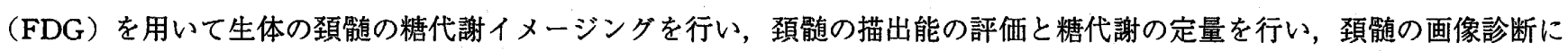
おける PET 検查の役割について検討した。

対象は21例の頭顏部腫瘍の患者と 3 例の椎間板ヘルニアによる頝䯣ミエロパチーの患者で, 頭頝部腫瘍の患者は MRI, CT 画像や臨床症状上, 中枢神経系に異常がなく, 頚䯣正常例とした。頭頚部腫瘍の患者のうち 8 例は 3 週間から 3 力月の 間隔をおいて化学療法および放射線療法の前後に 2 回の FDG-PET 検查を行った。撮影は $2 \mathrm{D}$ mode で $4.25 \mathrm{~mm}$ 間隔で 35 スライスの同時収集を行い, 再構成画像の横断方向, 軸位方向の空間解像度は半值幅 $4.2 \mathrm{~mm}$ であった。頚䯣描出能の評価 は矢状断，冠状断の再構成画像を用いて頝髄を上中下に分け，各々を 4 から 0 までの 5 段階で目視評価し， 2 以上を可視と 判断した。糖代謝の定量は可視と判断された対象の頝䯣の横断画像上に関心領域（ROI）を設定し，ROI 中の最大カウン トを組織トレーサー量とし，これを投与量および体重にて補正した standardized uptake value（SUV）を算出した。動脈 血採血を行った症例では Sokoloff の 3 コンパートメントモデルにて糖代謝率を算出した。

頚髄は上中下の各々で $81 ， 73 ， 57 \%$ 描出された。下位䅡髄のみの描出不良例は肩によるアーチファクトの影響であった。 頚䯣全体の描出不良例は体動による広範なアーチファクトの出現によると考えられた。

頭䅡部腫瘍に対する治療前後で 2 回の検査をうけた例で，頚髄のSUV 值に有意な変化は見られず再現性は良好であった。

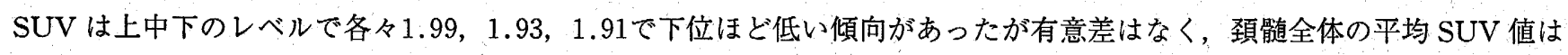

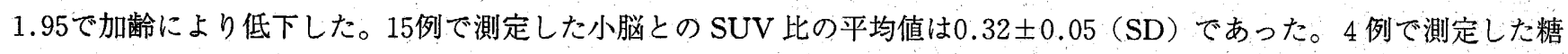
代謝率の平均值は $1.93 \pm 0.37 \mathrm{mg} / 100 \mathrm{~g} / \mathrm{min}$ であった。頝髄ミエロノメチー症例での顤骨道全体の平均 SUV 值は年齢を一致 させた正常例にくらべて低い傾向があった。

本研究により正常の頝髄は高分解能 PET を用いた日常の FDG-PET 検査において良好に描出でき，また頝髄の糖代謝 の定量評価が可能であると考えられた。頚部の FDG-PET 画像では頝髄の他に解剖学的指標となりうる構造がなく，頝髄 が良好に描出されることで頭䅡部病変の的確な局在診断が可能となり，また MR I など他の撮影法との画像の重ね合わせを 行う際にも有用と考えられた。また定量的評価を行うことで,ミエロパチーなどの頚䯣病変の評価の際に有用となる可能性 が示晙された。

\section{論文審 查 の 結 果 の要 旨}

ポジトロンCT (PET) を用いた生体の糖代謝イメージング技術の有用性は, 脊䯣の研究において確立されていない。本 


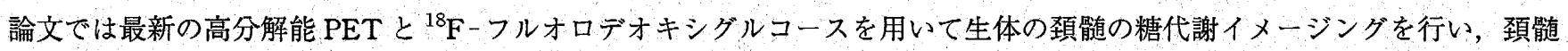
の描出能の評価と糖代謝の定量的評価により，䅡髄の画像診断における PET 検査の役割について検討した。

対象は21例の中枢神経系に異常がない頭䅡部腫場の患者と 3 例の椎間板へルニアによる䅡䯣症の患者で, 再構成画像の空 間解像度は半值幅 $4.2 \mathrm{~mm}$ であった。矢状断, 冠状断画像にて頝䯣を上中下に分けて目視評価し, 各々 $81,73,57 \%$ を描出 可能と判断した。下位䅡䯣のみの描出不良例は局によるアーチファクトの影響であったが, 頚䯣全体の描出不良例は体動に よる広範なアーチフアクトの出現によると考えられ, 適正に撮影が行われた場合, 䅡唱はPETにて十分描出可能と判断さ れた。頝髄の糖代謝率の平均値は $1.93 \pm 0.37 \mathrm{mg} / 100 \mathrm{~g} / \mathrm{min}$ であった。組織トレーサー量を投与量と体重にて補正した Standardized uptake value (SUV) による検討では, SUV 值は下位䅡䯣ほど低い傾向があったが有意差はなく，加齢によ る低下がみられた。頚髄症症例での䅡髄全体の平均 SUV 值は正常例にくらべて低い傾向があった。

以上の研究は生体の額䯣の画像診断における PET 検查の有用性の確立に貢献し, PET 検査の臨床応用の発展に寄与する ところが多い。

したがって, 本論文は博士 (医学) の学位論文として価值あるものと認める。

なお，本学位授与申請者は，平成13年 2 月 9 日実施の論文内容とそれに関連した試問を受け，合格と認められたものであ る。 